\title{
MARKETING TOOLS IN THE ERA OF DIGITIZATION AND THEIR USE IN PRACTICE BY FAMILY AND OTHER BUSINESSES
}

\author{
Naděžda Petrů1, Jan Kramoliš², Peter Stuchlík ${ }^{3}$
}

\footnotetext{
1 University of Finance and Administration, Faculty of Economic Studies, Business Management Departments, Czech Republic, ORCID: 0000-0002-9927-3337, 9895@mail.vsfs.cz;

2 Tomas Bata University in Zlin, Faculty of Management and Economics, Department of Economics, Czech Republic, ORCID: 0000-0002-1687-8067, kramolis@fame.utb.cz;

3 KORCHEM, s. r. o., Czech Republic, ORCID: 0000-0002-2515-6955, stuchlik@korchem.cz.
}

\begin{abstract}
This article addresses Marketing 4.0 as an exceptionally dynamic field for company competitiveness that is evolving rapidly. The main goal of this article is to evaluate and compare the overall level of use of modern marketing tools in practice by family and non-family businesses, and subsequently to measure the dependence between the extent of Marketing 4.0 activities and number of employees, volume of sales, field of business, and year the company was established. Primary and secondary data was analyzed using basic and advanced statistical methodologies, including the testing of six hypotheses.

The study showed that for both family and non-family businesses there has not been any significant increase in overall marketing vitality in the years studied. Indeed, the long-term focus of companies on values provided to customers and relationships with customers was confirmed. The results further showed that from the perspective of marketing vitality, one of the currently more significant weaknesses of smaller companies in particular of both family and non-family types is a missing or insufficient strategy for realization of marketing activities.

This study confirms the dependence of the level of overall marketing vitality on sales volume and company size by number of employees, but on the other hand no dependence was proven between marketing vitality on field of business or year company established.

This study evaluates the liminality and states that family businesses above all others address what is for them the more important strategic question, namely that of succession. The study is unique in that it compares the results of three studies carried out between 2016 and 2019. The context of this study is framed by an appeal to eliminate barriers to change and rapid response by companies to the needs, requirements, and expectations of customers operating in the online world.
\end{abstract}

Keywords: Family business, non-family business, trend tools, marketing vitality, Marketing 4.0, digitization.

JEL Classification: F40, L60, M20.

APA Style Citation: Petrů, N., Kramoliš, J., \& Stuchlík, P. (2020). Marketing Tools in the Era of Digitization and Their Use in Practice by Family and Other Businesses. E\&M Economics and Management, 23(1), 199-214. https://doi.org/10.15240/tul/001/2020-1-014

\section{Introduction}

In this era of digital commerce, information is forever appearing on the markets testifying to the importance of using the tools of modern marketing. Indeed, one of the theories of this new grouping of tools is designated as "Marketing 4.0". This trend encompasses concepts such as "thinking virtually", using social networks for expansion to international markets and other objectives, content marketing, copywriting, 
engagement marketing, etc. As the Marketing 3.0 concept stands widely endorsed, Marketing 4.0 is an approach which more effectively takes into account the convergence of the offline and on line worlds of businesses and customers. The concept focuses on how, in the times of a digital economy boom, offline touch serves as a major differentiation in an increasingly online world (Kartajaya \& Setiawan, 2018; Negricea \& Purcarea, 2018). It is understandable that for companies who wish not only to survive in the market but also to grow, it is essential that these new concepts in the field of marketing be taken into consideration.

The essential issue lies in determining the total level of use of effective tools of modern marketing, including the tools of Communication 4.0 in companies. This is followed by the detection of dependencies between the level of marketing activities and number of employees, volume of sales, field of business, and year the company was established.

\section{Theoretical Background}

Marketing 4.0 is the sequel to our widelyrecognized concept of Marketing 3.0, which calls for brands to touch the human spirit. Marketing 4.0 is based on intricate observation and analysis of the paradoxes in view of the digital technology boom. This concept explain how online meets offline (Kartajaya \& Setiawan, 2018). Elements of Marketing 4.0 according to Kartajaya and Setiawan (2018):

From 'Segmentation and Targeting' to 'Customer Community Confirmation'; From 'Brand Positioning and Differentiation' to 'Brand Characters and Codes'; From 'Selling the 4P's' to 'Commercializing the 4C/4S/4E' (mix customer, internet, emotional, etc.).

\subsection{Family Businesses}

Family businesses differ from other businesses primarily in the specific features of people management, namely managing (family) relationships, and in economic terms (frugality, reinvestment of profits into further company growth, etc.). From an ethical perspective and in terms of political and economic philosophy, family is considered a suitable environment for the creation of young people's economic attitudes (Horčičková \& Stasiulis, 2019; Klučnikov, Sombeková, \& Majková; 2016). Its primary goal is to hand the company down to subsequent generations. Other (non-family) businesses are defined as businesses that themselves do not identify as family businesses, and in which a family does not have any majority share of ownership. Its primary objective is return on investment/profit, achieved through the alignment of objectives of owners and management (Westhead, 1997). Family owned and managed businesses play a central role in most of the world's economies. They are among the oldest and longest-standing organizational forms (Cailluet et al., 2018; Kamei \& Dana, 2012). For some time family businesses have been key elements of the commercial environment, appearing in all industries (Gottschalk, 2017; Jelínková \& Jiřincová, 2015) and creating a substantial benefit for the economy (Dana et al., 2015; Rahman et al., 2017; Petrů, Pavlák, \& Polák, 2019). They play an important role in employment, income generation, and accumulation of wealth (Colli \& Rose, 2014; Dana \& Ramadani, 2015; Ramadani \& Hoy, 2015).

In the United States, almost half of all companies are managed by families. In Europe family businesses create over 5 million jobs (Ferramosca \& Ghio, 2018). These businesses contribute significantly to gross domestic product (Osunde, 2017) and have a tendency to be great innovators with long-term vision (Kammerlander \& Essen, 2017; Acosta-Prado et al., 2017; Serrano-Bedia et al., 2019; Kraiczy, 2013). The general concept of a family business includes any companies in which a majority share of ownership or control is held by a family and in which two or more family members are directly involved (Shi, 2014). A family business is a complex system that combines family, entrepreneurialism, and property management (Dana \& Ramadani, 2015). A family business integrates family, ownership, and management, whereas its administration typically does not differ from its leadership (Davis, 2017; Tagiuri \& Davis, 1996; Habbershon et al., 2003). Family members who are involved in this type of business are part of a family and corporate system (Dana \& Ramadani, 2015). These businesses are exceptionally difficult to describe because they are multidimensional and no unified definition can completely capture their internal diversity (Colli \& Rose, 2016; Even, 2017).

The issues associated with managing a family business, unlike non-family businesses, must be identified in light of the distinctive 
internal climate of this type of business. In it an interaction takes place between a hypercompetitive business environment, family relationships, the need to manage family know-how, and the need to manage family assets across several generations, which can be a source of success and optimism but also a number of specific conflicts (Petrů, 2018). In order for a family business to have a chance at successful transfer to successor generations, it must monitor, evaluate, and actively implement modern marketing tools. This reality has been validated by Quaye and Mensah (2019). According to their research companies must integrate specific resources and capabilities, apply innovative marketing processes with the option for dynamic marketing, and thereby create sustainable market value. The theory of general business vitality is described by Plamínek (2014). It is based on the findings that achieving vitality is dependent on mastering four key disciplines: usefulness, efficiency, stability, and dynamism.

\subsection{Marketing and its Trend Tools}

Marketing and marketing management is an extraordinarily dynamic field that is evolving quite rapidly. Its power lies in an ability to think in terms of marketing and to approach customers in terms of marketing (Petrů et al., 2018). Marketing is also defined as a culture emphasizing the primary importance of customers at an organizational level (Vorhies et al., 2015). What is important for the future is a transition from mass off-line marketing to online marketing that appears to the customer by a digital route (Raab et al., 2016). Examples of this include SEO and SEM, customized web pages, personal email campaigns, mobile marketing, the use of chatbots, IoT, BigData analysis, an analytics of traffic and conversions in the online environment.

As digital economy booms and smartphones become more ingrained in consumers' lifestyles - deeply influencing their attitudes and behaviors - consumers will increasingly look for the perfect mix of tech that makes their lives easier, complements their goals of selfactualization and nurtures a deeper sense of 'doing good'. Companies need to adaptation in the run up to a fast-developing digital economy. They need novel marketing approaches, which would help them anticipate and leverage on these unprecedented disruptive innovations
(Kartajaya \& Setiawan, 2018). The authors Vacek and Zbránková (2017) are also of the opinion that the future of marketing is decidedly in technologies. Marketing communication is based on interaction, the ability to listen and understand customers and their needs. And finally, as connected devices become more commonplace on the back of artificial intelligence and loT, resulting in greater marketing productivity, in order to strengthen customer engagement (Kartajaya \& Setiawan, 2018).

The marketing strategies of family and non-family businesses differ depending on their individual areas of business. And yet in the digital age they are unified by one thing - the creation or servicing of the needs, requirements, and expectations of today's digitally integrated customers and markets (Duke Perspective, 2019). Sabaitytè et al. (2019) likewise state that if the goal is to increase companies' competitiveness and execute effective marketing activities, it is important to identify the significant elements of virtual customer behavior and influence their purchasing decisions. A globaly renowned studies (Stankovska et al., 2016; Nurita \& Lundia, 2017; Kotler et al., 2017) identify the effort of companies to overcome barriers, accept progress, make use of the potential of digital channels, particularly social media, and to accept the standardized, interactive, and ubiquitous tools and technologies of Marketing 4.0.

Companies are forced to develop strategic approaches focused on customers. The research of Thrassou et al. (2018) appeals to the concept of "consumer value". This value is often touted for example as agile innovation at the strategic marketing level, and appears to be a natural and real competitive advantage. According to Parada and Gimeno (2016), family businesses can successfully transfer their basic value through stories, individual profiles of the personalities representing the specific generations. On what basis should family businesses build the online presentation or competitive advantage of their companies? In 2010 Ceja, Agulles and Tàpies summarized the findings of Anderson and Reeb (2003), Denison, Lief and Ward (2004) and Tàpies et al. (2008) from research into the importance of values for the success of family businesses. They defined, classified, and compiled a hierarchy of values 
acknowledged by families doing business. Apart from integrity, respect, and building relationships with customers, family business value humility, open communication, quality, excellence, creativity, industry, company name, tradition, responsibility, long-term perspective, etc.

Modern communications technologies now allow customers a much higher degree of informedness than ever before. Potential and loyal customers regularly verify the quality of all companies (regardless of their status as family businesses or otherwise), and from these select the best options for themselves, guided by the recommendations of their acquaintances, friends, or discussion forums (Word of Mouth marketing).

The research of Binz Astrachan and Botero (2018) yielded the finding that not all family businesses actively communicate the brand of their family business and the values associated with it. Based on a review of a thousand websites for family businesses, the researchers reached the conclusion that 43 percent of the companies did not explicitly communicate the involvement of the family in the business. Binz Astrachan and Astrachan (2015) suggest that the promotion of family ownership and values is particularly important in contexts when personal interaction and unique craftsmanship or custom production serves as a differentiator between companies. Customers whose needs are expressed on one hand in their demand for a quality product, but also in demand for additional intangible added value, are sensitive to the "personality of the brand". They link it with anthropomorphic associations, such as a specific lifestyle, values, or attitude. The brand becomes a non-verbal carrier of information about them themselves (Chebbi et al., 2013). A family/non-family business that appeals to positive emotions, creates a brand, and actively and creatively communicates it using the tools of Marketing 4.0., can be considered an excellent brand.

The future success of family and non-family businesses is also a product of the ability of management to manage relationships with customers. A new phrase associated with CRM is Electronic CRM 4.0. It is based on the consolidation of traditional CRM with the market of electronic commerce applications, including a wide range of information technologies used for support of the CRM strategy of the company
(Hamdan \& Triayudi, 2019). Electronically managed relationships with customers (e-CRM) has become the newest paradigm in a world driven by customer relations (Mashchak \& Dovhun, 2020).

\section{Objective, Methodology, Data}

The chief goal of this primary quantitative research was to assess and compare the overall level of use of modern marketing tools in practice by family and non-family businesses on the basis of a point assessment (per Tab. 1). Subsequently to detect dependencies between the level of marketing activities and number of employees, volume of sales, field of business, and year the company was established.

To obtain a random sample of respondents from the ranks of family businesses, a list of family businesses was used that has been compiled by VŠFS since 2015. As of the start date of the study, it contained information verified against the ARES database of economic entities on 3,629 active business entities. Primary data collection was performed by trained field operatives in the form of primary qualitative research/semi-structured interviews.

Other information was obtained from 424 companies in the Czech Republic. Of this 420 records were usable, as 4 of these records suffered from loss of data due to transmission and formatting. The ratio between non-family and family businesses reviewed was $23 / 77 \%$, which allowed for statistically significant comparisons to be drawn. After the elimination of incomplete or inaccurate data, the original number of 420 usable records was reduced to 370 , which were used for all calculations, i.e. $88 \%$ were valid.

The average values of marketing vitality are compared via time series with the outputs of previous studies (probe focused on the level of use of modern marketing tools carried out by VŠFS in $2016-n=109$, to research in the year $2018-n=264$ ). The statistical evaluation is performed using the Coefficient of Variation, Pearson Coefficient, and Student's Criteria.

The study sample was tested from a perspective of completeness of test variables using the program SPSS. The study sample met completeness of data at $100 \%$. The reliability of test data was then validated using Cronbach's Alpha. The Cronbach's Alpha value is 0.887 , which indicates a good value of acceptability. Based on this value, the study data may be 
declared reliable. For this reason the results and conclusions presented may be accepted with a high degree of probability.

The following factors were also used as independent variables in the computation: year founded, category of company size, and field of business according to the CZ-NACE categorization. The factors of revenues and overall assessment of "marketing vitality", as well as eight topics of questions from the survey (marketing plan, segmentation, customer relations management, use of new communications technology, approach to social responsibility, brand management, values provided to customers, assessment of effectiveness of marketing activities) were used as dependent variables. Given that the revenues of each business ascribed to a specific year by financial statements are the result of work from a longer period than that taxable in a typical year, and likewise that the number of employees covers a longer period than one year, this data was handled as continuous functions. Year founded and field of activity are discrete quantities and were processed accordingly.

Given the scope of the data and the goal, primitive methods of descriptive statistics were used to evaluate the acquired data, namely sum and average. For the average the standard deviation and variation coefficient were not evaluated, as there would be nothing to compare them to given the diverse character of the individual categories, or this could have amounted to skewing data without substantial reporting capabilities. Correlations, in various forms, are the most common statistical characteristics. The purpose of the correlation analysis is to determine the mutual relationship of the given quantities. Dependencies between variables were determined using the method of calculating the Pearson correlation coefficient, which measures the strength of the linear dependency between two quantities. The results of correlation analysis are used to confirm or refute hypotheses. Correlation analysis was performed using the statistics program IBM SPSS ver. 25. The results of the correlation analysis are listed in Tab. 3.

Marketing vitality was evaluated in Tab. 1 according to four point ranges.

\subsection{Research Questions and Hypotheses}

In order to achieve the goals of this research, two research questions were articulated and hypotheses assigned to them as follows:

$R Q_{1}-H_{1}, H_{2} ; R Q_{2}-H_{3}, H_{4}, H_{5}, H_{6}$.

$R Q_{1}$ : Is it possible to record progress since 2016 in the use of tools of modern marketing?

$H_{1}$ : Companies effectively use marketing tools if they have an average point assessment

\section{Tab. 1: Point assessment ranges}

\begin{tabular}{l|l|l|l}
\multicolumn{1}{c|}{ A (1) } & \multicolumn{1}{c|}{ B (2) } & \multicolumn{1}{c}{ C (3) } & \multicolumn{1}{c}{ D (4) } \\
\hline 0-10 points & \multicolumn{1}{c|}{ 11-33 points } & \multicolumn{1}{c}{ 34-67 points } & \multicolumn{1}{c}{ 68-100 points } \\
\hline Not yet initiated & $\begin{array}{l}\text { Definite verifiable } \\
\text { progress }\end{array}$ & $\begin{array}{l}\text { Substantial verifiable } \\
\text { progress }\end{array}$ & Objective fully achieved \\
\hline $\begin{array}{l}\text { Almost nothing is } \\
\text { happening, only } \\
\text { perhaps some good } \\
\text { ideas, primarily from } \\
\text { the owner, which } \\
\text { nonetheless do not } \\
\text { continue further than } \\
\text { the objective. }\end{array}$ & $\begin{array}{l}\text { There is certain } \\
\text { evidence to indicate } \\
\text { that something useful in } \\
\text { the area being studied } \\
\text { is actually happening. }\end{array}$ & $\begin{array}{l}\text { There is unambiguous } \\
\text { evidence that the area } \\
\text { being studied is being } \\
\text { properly addressed. } \\
\text { Regular and routine } \\
\text { analyses are conducted } \\
\text { and ongoing refinement } \\
\text { of the individual } \\
\text { activities is taking place. }\end{array}$ & $\begin{array}{l}\text { Excellent approach } \\
\text { or result, the activity } \\
\text { is implemented in the } \\
\text { full extent, in all areas } \\
\text { and aspects. This is } \\
\text { a model solution or } \\
\text { success achieved, } \\
\text { it is difficult to expect } \\
\text { further substantial } \\
\text { improvements apart } \\
\text { from the expansion of } \\
\text { positive trends. }\end{array}$ \\
\hline
\end{tabular}


of the individual marketing tools studied of no less than of 61 points.

$\mathrm{H}_{2}$ : There is a significant difference between the overall marketing vitality of family and nonfamily businesses.

$R Q_{2}$ : How does overall marketing vitality correspond with the amount of sales, the field of business, the size of the company, and the year the company was founded?

$\mathrm{H}_{3}$ : There is a statistically significant dependence between marketing vitality and revenue.

$H_{4}$ : There is a statistically significant dependence between marketing vitality and field of business.

$H_{5}$ : There is a statistically significant dependency between marketing vitality and company size.

$H_{6}$ : There is a statistically significant dependence between marketing vitality and the year the company was founded.

For $\mathrm{H}_{2}$, a significant difference is defined as a difference of $30 \%$ or higher in the overall assessment. A 10\% difference accounts for the error rate of each process and measurement methodology. Only a difference greater than $10 \%$ can be considered statistically significant. In order for the selected threshold to be categorically significant, a value of $30 \%$ was used, which exceeds the Parents rule. A statistically significant dependence is defined by the Pearson coefficient for $\mathrm{H}_{3}: 0.80-1.0$; $\mathrm{H}_{4}: 0.40-0.59 ; \mathrm{H}_{5}: 0.60-0.79 ; \mathrm{H}_{6}: 0.20-0.39$.

\section{Results}

The first research question $\left(R Q_{1}\right)$ focused on the issue of whether it is it possible to record progress since 2016 in the use of tools of modern marketing. The comparison of average point assessments achieved for the individual indicators using the time series method between family and non-family businesses is depicted in Tab. 2. From the results it is clear how the activities performed fall under the individual indicators.

Tab. 2 depicts the time series of the point assessment of studies from 2016, 2018 and 2019. The measured values are shown in the individual lines, for the individual years under review, as well as the average point value. From the results presented it is clear that both with family and non-family businesses there has not been any significant increase in overall marketing vitality in the years studied. The

\begin{tabular}{|c|c|c|c|c|c|c|c|}
\hline \multirow[b]{3}{*}{ Evaluated activity } & $\begin{array}{l}\text { eries of } \\
18 \text { and }\end{array}$ & $\begin{array}{l}\text { oint ass } \\
019\end{array}$ & sment & ording & outpu & f rese & \\
\hline & \multicolumn{4}{|c|}{ Family businesses } & \multicolumn{3}{|c|}{ Non-family businesses } \\
\hline & $\begin{array}{c}2016 \\
(n=109)\end{array}$ & $\begin{array}{c}2018 \\
(n=214)\end{array}$ & $\begin{array}{c}2019 \\
(n=285)\end{array}$ & $\begin{array}{c}\text { Average } \\
\text { point } \\
\text { value }\end{array}$ & $\begin{array}{c}2018 \\
(n=50)\end{array}$ & $\begin{array}{c}2019 \\
(n=85)\end{array}$ & $\begin{array}{c}\text { Average } \\
\text { point } \\
\text { value }\end{array}$ \\
\hline Marketing plan & 39.0 & 35.7 & 29.3 & 34.7 & 36.6 & 38.3 & 37.5 \\
\hline Customer segmentation & 52.0 & 45.9 & 44.0 & 47.3 & 45.2 & 53.0 & 49.1 \\
\hline $\begin{array}{l}\text { Relationships with } \\
\text { customers }\end{array}$ & 57.0 & 50.1 & 61.5 & 56.2 & 53.5 & 52.3 & 52.9 \\
\hline $\begin{array}{l}\text { New communication } \\
\text { technologies }\end{array}$ & 39.0 & 37.6 & 34.9 & 37.2 & 43.8 & 53.9 & 48.8 \\
\hline $\begin{array}{l}\text { CSR and its } \\
\text { communication }\end{array}$ & 39.0 & 45.0 & 49.5 & 44.5 & 49.3 & 41.8 & 45.6 \\
\hline Brand management & 43.0 & 33.1 & 34.0 & 36.7 & 33.9 & 37.3 & 35.6 \\
\hline $\begin{array}{l}\text { Values provided to } \\
\text { customers }\end{array}$ & 58.0 & 58.7 & 63.1 & 59.94 & 54.4 & 52.0 & 53.2 \\
\hline Evaluation of efficiency & 36.0 & 47.4 & 36.8 & 40.06 & 44.9 & 49.0 & 47.0 \\
\hline Average point value & 45.3 & 44.2 & 44.1 & 44.5 & 45.2 & 47.0 & 46.1 \\
\hline
\end{tabular}




\begin{tabular}{|c|c|c|c|c|c|c|}
\hline \multirow{3}{*}{ Evaluated activity } & \multicolumn{2}{|c|}{$\begin{array}{l}\text { Coefficient } \\
\text { of variation }\end{array}$} & \multicolumn{2}{|c|}{ Pearson coefficient } & \multicolumn{2}{|c|}{ Student's criterion } \\
\hline & 2018 & 2019 & 2018 & 2019 & 2018 & 2019 \\
\hline & & & 0.9095 & 0.4944 & 0.8013 & 0.5625 \\
\hline Marketing plan & 0.2 & 21.2 & & & & \\
\hline Customer segmentation & 0.1 & 20.3 & & & & \\
\hline Relationships with customers & 2.9 & 21.2 & & & & \\
\hline $\begin{array}{l}\text { New communication } \\
\text { technologies }\end{array}$ & 9.6 & 90.3 & & & & \\
\hline CSR and its communication & 4.6 & 14.8 & & & & \\
\hline Brand management & 0.2 & 2.7 & & & & \\
\hline Values provided to customers & 4.6 & 30.8 & Diff & nce & & \\
\hline Evaluation of efficiency & 1.6 & 37.2 & 2018 & 2019 & & \\
\hline Average point value & 0.3 & 2.1 & -1.0 & -2.9 & & \\
\hline
\end{tabular}

same can be said for the individual assessed indicators. To verify accuracy, the results were tested according to the Pearson coefficient, variation coefficient, and Student's distribution. All three tests showed that the results obtained for the year 2019 are not probable and reflect a high error rate. See Tab. 2 and 3 . It is not therefore possible to reach the categorical and valid conclusion that no progress in marketing vitality has occurred among the companies studied, nor can the average valid values of the point assessment of marketing vitality from 2019 be denied.

As regards $\mathrm{H}_{1}$, how effectively companies use marketing tools - the results are depicted in Tab. 3. Ratings above the expected 61 points were achieved by 85 family businesses $(29.82 \%$ of the total number of family businesses, the highest achieved average point assessment had a value of 91.25 points) and 14 non-family businesses $(16.28 \%$ of the total number of family/non-family businesses, the highest average points assessment achieved had a value of 75 points). Companies of family and non-family businesses in the previous years of 2016-2019 comparably achieve point values above 61 points only in the indicator Relationships with Customers and Values Provided to Customers. In the total assessment of marketing vitality studied by the company, the boundaries established for effective use of marketing were not achieved, even taking into account the unreliable results from the year 2019. This is because the worst variation coefficient was produced in the categories where companies report the best values, it can be presumed that distorted data was obtained for these respondents. $H_{1}$ has therefore been controverted.

Analysis of the difference in overall marketing vitality between family and nonfamily businesses $\left(\mathrm{H}_{2}\right)$ - the results are shown by Tab. 3. The total average score using specific marketing activities with the individual indicators ranges for studied companies between 1.5-91.25 points. Family businesses achieved an average rating of 44.12 points, whereas nonfamily businesses had an average evaluation of 47.03 points. This is almost an identical result. The difference determined in 2018 amounts to merely $1 \%$ and in 2019 amounts to $2.9 \%$ to the benefit of non-family businesses. Such a difference is within the boundaries specified for process error and cannot be considered significant. All marketing tools studied were tested for 2018 and 2019 using the variation coefficient. From the results it is clear that the greatest errors in the results received were achieved for the year 2019 and for the tools New Communications Technologies and Value 
transferred to the customer. Nonetheless, taking into account the decreased reliability of the results from the year 2019, it can be stated that there is no significant difference for average value of marketing vitality between family and non-family businesses for the years 2018 and 2019. The variation coefficient confirmed this result. $\mathrm{H}_{2}$ has therefore been controverted.

The second research question $\left(R Q_{2}\right)$ addressed the issue of how overall marketing vitality corresponds to other factors such as: volume of sales, field of business, size of company, and year company founded. Given that the point assessment between family and non-family businesses did not indicate a statistically significant deviation, the search for dependence subsequently worked with both groups of respondents at once $(n=370)$. The dependence of overall marketing vitality is listed in the following Fig. 1-4. In the individual graphs the term "marketing vitality" is hereafter listed solely as "MV". The individual factors for which dependences with marketing vitality were sought are listed as follows: Average Sales as AS; Classification of economic activities as CEA; Number of Employees as NE; Year company establishment as YCE.

From the Fig. 1 it is clear that the growth of sales (AS) led to an overall tendency toward slight growth in the average point assessment of marketing vitality, but only for the category from CZK 1,001-3,000 thousand. The tail of the curve cannot be considered evidential due to the small number of companies studied in this category. From the volume of sales (CZK 3,000 th.) the level of marketing activities is not a decisive factor for market success.

The second area addresses the dependence of MV and field of business, CEA (Classification of economic activities). CEA is determined according to the national classification " $\mathrm{CZ}$ NACE". In the Fig. 2 only basic classifications are given. These classifications are designated using numbers from 1 to 9 : where 1 = the food industry, footwear, apparel, woodworking; 2 = wood harvesting, chemical and pharmaceutical industry, manufacturing of construction materials, steelworking and processing metals, electrical devices and electronics, engines and machines, motor vehicles; 3 = ships, aircraft, locomotives, and other modes of transportation, furniture, other processing industry, manufacturing and distribution - electrical power, gas, and heat, water management, waste management; $4=$ construction, wholesale and retail, ground transport; $5=$ water and air transportation, storage, accommodations, dining and hospitality, publishing; 6 = radio, television, telecommunications, IT, banking, insurance, real estate; 7 = company management, engineering activities, research and development, promotions, special services, veterinary care, leasing, agency services; 8 = security, housekeeping, brokering, public administration and defense, education, social care, outpatient treatment; 9 = artistic activity, library, games and

\section{Fig. 1: RQ2 - Dependence of marketing vitality assessment on volume of sales (AS)}

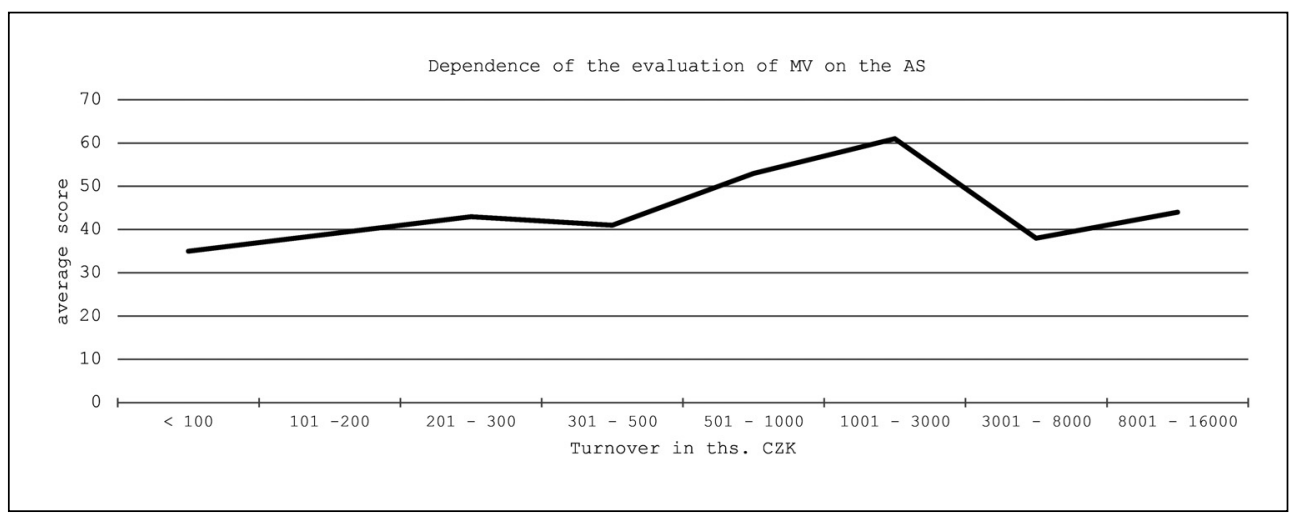




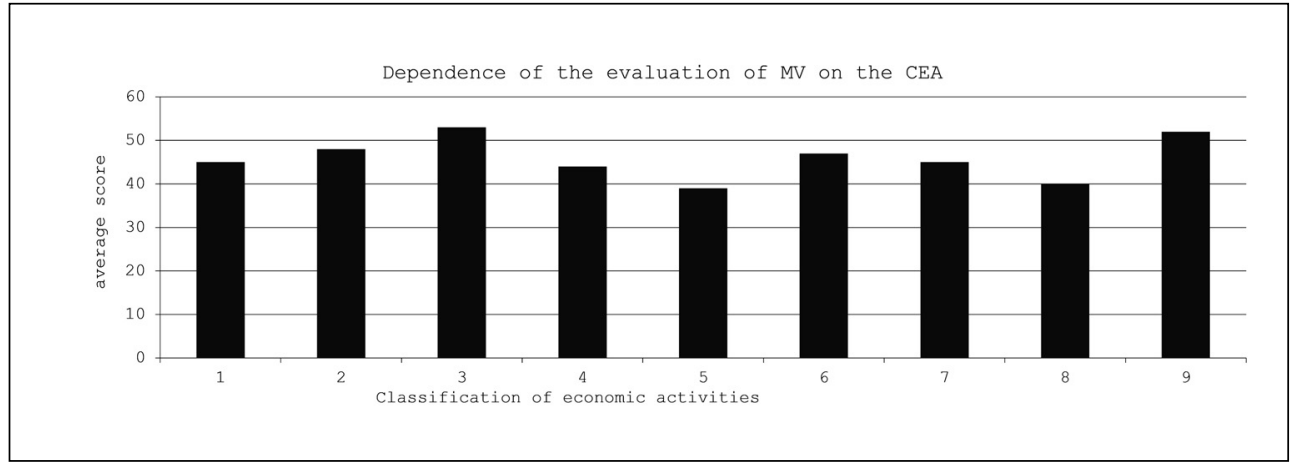

Source: own research

casinos, professional organizations and unions, repairs, household activities, mining and support industries.

Only two fields -3 and 9 , which were both represented by 18 companies $(4.35 \%$ of respondents) achieved an overall point assessment higher than 50 points. Field 3 was represented primarily by companies from the processing industries, which are often dependent on multinational firms due to their sub deliveries, which require a higher degree of marketing activities. Or this consists of companies offering products made to order (e.g. furniture). These companies must present their offering at high quality on B2C markets and appeal to their originality, high quality, design, etc. Field 9 - artistic activities - is in itself associated with creativity, imagination, and marketing vitality.

Fig. 3 indicates that the level of marketing vitality grows with increases in the number of employees. In comparison, companies with employee numbers below 99 are forced to address operating problems and lack the staff to focus on strategic marketing management on top of their own work. This claim applies also to the size of the company characterized by numbers of employees of less than 499.

\section{Fig. 3: RQ2 - Dependence of vitality evaluation on the size of the company by the number of employees (NE)}

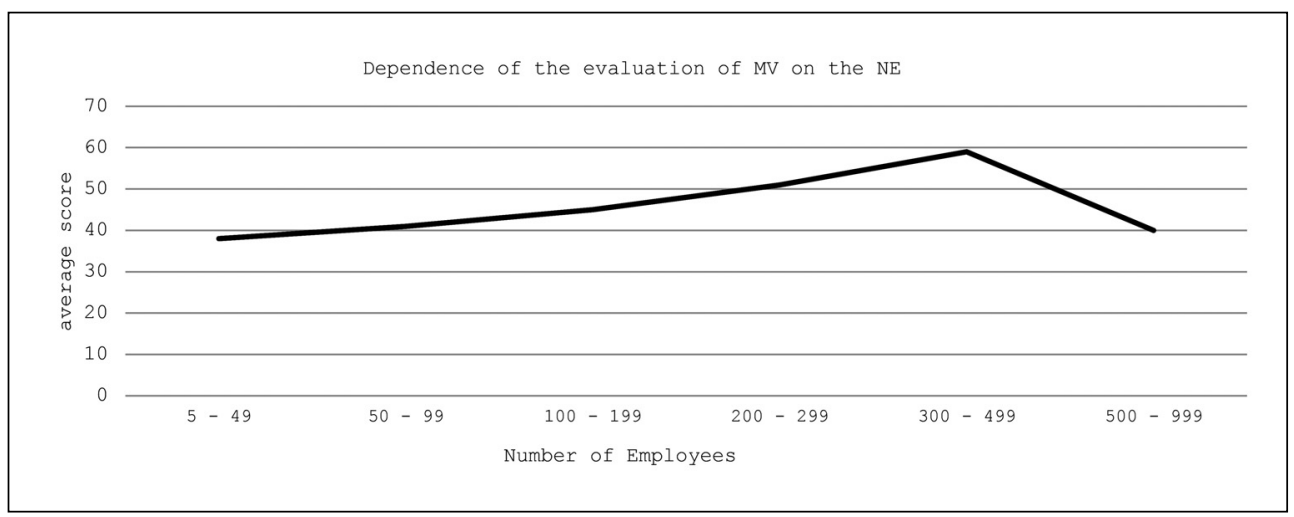




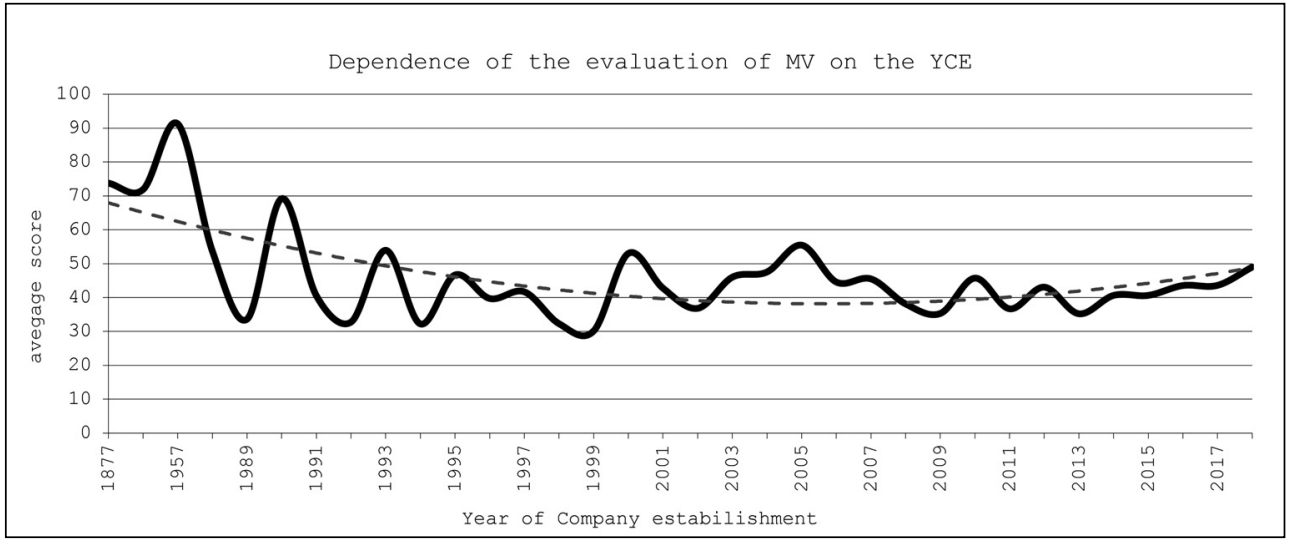

Source: own research

For companies founded after 2015, which began operating in a strong competitive environment, awareness of marketing as a tool of competitive advantage is most likely growing. Fig. 4 shows the dependence of the evaluation of MV on YCE, supplemented with a polynominal trendline.

The specified hypotheses assigned to research question $R Q_{2}$ were tested on the basis of calculations of the Pearson correlation coefficient performed. Results are stated in Tab. 4.

Evaluation of hypothesis $\mathrm{H}_{3}$ : from testing it can be seen that this hypothesis has been confirmed. If the value of the Pearson correlation coefficient is within the range of $r=0.80-1$, this may be defined as a very strong dependence between marketing vitality and volume of sales. In the event that Pearson is calculated from all data, its value results at $\mathbf{0 . 6 4}$. This is due to the fluctuation of overall assessment for sales above the category of CZK 1,001-3,000 th. - it would be necessary to controvert this hypothesis. If, however, it is calculated from data up to this value, the value of the coefficient is $\mathbf{0 . 9 1}$. The hypothesis can therefore be confirmed in the defined interval.

Hypothesis $\mathrm{H}_{4}$ : "There is a statistically significant dependence between marketing vitality and field of business", was disproved by testing. If the value of the Pearson correlation coefficient is within the range of $r=0.40-0.59$, this may be defined as a moderate dependence between marketing vitality and field of business. This hypothesis was therefore controverted, the resulting value of 0.127 testifies to a very weak dependence.

Hypothesis $\mathrm{H}_{5}$ : "There is a statistically significant dependence between marketing vitality and company size", was confirmed by

\section{Tab. 4: Correlation analysis of the level of marketing vitality and selected factors}

\begin{tabular}{l|l|c|c|c|c}
\multicolumn{2}{c|}{} & AS & CEA & NE & YCE \\
\hline \multirow{2}{*}{$\begin{array}{l}\text { Average Score } \\
\text { of MV }\end{array}$} & Pears. correlation & .912 & $.127^{\star *}$ & $.715^{\star *}$ & $.540^{\star *}$ \\
\cline { 2 - 6 } & Sig. (2-tailed) & & .000 & .000 & .000 \\
\cline { 2 - 6 } & $\mathrm{N}$ & 370 & 370 & 370 & 370 \\
\hline
\end{tabular}

Source: own research

Note: ${ }^{* *}$ Correlation is significant at the 0.01 level (2-tailed) (this means high quality statistical data at the level of a $1 \%$ deviation). 
testing. If the value of the Pearson correlation coefficient is within the range of $r=0.60-0.79$, this may be defined as a strong dependence between marketing vitality and company size by number of employees. This hypothesis was therefore confirmed, the resulting value of 0.715 indicates a strong dependence.

Hypothesis $\mathrm{H}_{6}$ : "There is a statistically significant dependence between marketing vitality and year the company was founded", was controverted by testing. If the value of the Pearson correlation coefficient is within the range of $r=0.20-0.39$, this may be defined as a weak dependence between marketing vitality and year of founding the company. This hypothesis was therefore controverted, the resulting value of 0.540 indicates a moderate dependence.

\section{Discussion}

The research results demonstrate that the total level of marketing activities of (mostly smaller) Czech companies, both family and non-family in type, is relatively low, and yet they have been successful in the market (based on an assessment of trends in sales and long-term operations on the market. A real finding from the semi-structured interviews leads to the conclusion that the classical tools of the "marketing mix", segmentation, marketing communication, etc. are used by owners intuitively without them realizing that they are actually performing their activities in a marketing way. Owners of companies instead seek an answer to the question of whether the tools of Marketing 4.0, e-CRM, etc. offer a benefit, and what kind - owners of family businesses instead see investment or the need to execute a change rather than a real and immediate influence on the purchasing behavior of the customer or increased visibility of the company. The reason could be lack of technical information and knowledge, faith in digitization as such or lack of time to devote more attention to the issues. Companies founded after 1989 are more focused on succession planning, operations management, HR issues, etc.

Among marketing activities they focus on verified methods - Relationships with customers and Value provided to customers. This finding is compatible with the outcomes of the study by Vorhies et al. (2015). Foreign studies (Ceja, Agulles, \& Tàpies, 2010; Anderson \& Reeb, 2003; Denison, Lief, \& Ward, 2004; Tàpies \&
Ward, 2008; etc.) declare that the competitive advantages of family businesses are social/ psychological, with emotional values such as integrity, respect, building relationships with customers, humility, open communication, quality, excellence, creativity, industry, and longterm perspective. Owners of Czech companies with regard to the tool Relationships with customers and Values provided to customers communicate values such as stability, reliability, trust, flexibility, uniqueness, speed of decisionmaking, tradition, good name, precision, fair dealing, common sense, quality, narrative, openness, connection to locale, reinvestment, activities performed with love, care. The values stated do not differ significantly from foreign studies. The designation of a family company, family business evokes a feeling of traditional quality, thorough craftsmanship - in other words, positive emotions. The term "family business" in its contemporary rendering represents a purposeful managerial/marketing construct that can support the economic functioning of the company and be a marketing competitive advantage in and of itself.

Owners of companies take consider their primary marketing goal to be highquality fulfillment of the real and actual needs, requirements, and expectations of the customer. Studies by Sujitha and Johnson (2017), Rosalina, Hamdan and Triayudi (2019) reference the importance of using information technologies. If the customer operates in the online environment and uses trend technologies, the company must subsequently adapt. Surprisingly, our investigation demonstrated that in most cases this is not the case with the studied companies in the area of new technologies.

The second research question $\left(R Q_{2}\right)$ addressed the issue of how overall marketing vitality corresponds to other factors such as: volume of sales, field of business, size of company, and year company founded. It was determined that sales growth (AS) leads to an overall tendency to increase marketing vitality. What is debatable is the question: what is the cause and what is the effect? The goal of investment in marketing activities is to influence the purchasing decision of the customer, but the final measurable goal is higher revenues, by extension higher profits. The expected impact of effective investment in marketing is an increase in revenues. And yet if a company 
has higher revenues, larger profits, can it invest more in marketing activities? The issue could lie in subsequent investigations analyzed in detail.

Only two fields -3 and 9 achieved an overall point assessment higher than 50 points. And yet the majority of respondents was reflected in field 4 , where their average point assessment reached a value of 43 points. The companies studied in many cases operate in multiple fields (e.g. agriculture - retail - wholesale accommodations); for the needs of this study, however, only the first field of business listed in the Commercial Register was evaluated. It can be assumed that the success of the analyzed companies does not consist of the field of their business but in their ability to discovery gaps in the market, in their relative flexibility, the speed of their response to market changes and requirements, in their relatively high capability to absorb work force in the given region, in their capability to fill the gap in the structure of commercial relationships between large companies (the role of subcontractor) or in their ability to produce custom products according to a customer PPO.

With growth in employees the level of marketing vitality grows as well - the company clearly has incorporated employees who focus on marketing or collaborate with external advertising agencies. In the creation and execution of marketing strategy with the use of modern communications tools, companies with a lower number of employees have significant reserves. Nonetheless it can be assumed that their success consists in social networks and relationships with employees, suppliers, and customers, in their corporate social responsibility activities in the region where they work and mostly live.

There is a moderate dependence between marketing vitality and year of founding the company. Companies founded prior to 1989 most likely built on family tradition and made use of original brands, and now in their communications activities apply an appeal to a "brand with tradition" - e.g. Petr of brand with tradition since 1864, and so forth. For owners of companies founded after 2015, a higher level of awareness is presumed for marketing as a tool of competitive advantage.

\section{Conclusions}

The goal of this article was to evaluate and compare the overall level of use of modern marketing tools in practice by family and nonfamily businesses, to measure the dependence between the level of Marketing 4.0 activities and the number of employees, volume of sales, field of business, and year the company was established. It cannot be doubted that the alpha and omega of corporate success is a satisfied customer. Many of these customers today commonly navigate the online environment quite well and use various communications channels in various ways in the different phases of their purchasing behavior. In digital marketing it is more than just a question of finding the right combination of channels, messaging, and format, but above all of the capability of the company to attract customer attention in a creative, novel way. As the research shows, such marketing in most cases is neither seen nor executed by the owners of the companies under study.

Based on the comparison of time series results of assessment of marketing vitality from 2016-2019 it can be stated that particularly with small companies, practicality, intuitive attitude, and an adventurous outlook predominate. Among the individual marketing tools/ methodologies, attention is devoted primarily to personal development of relationships with customers and value/emotional marketing presented via psychosocial, non-financial, intangible added value to expected quality products. A topic of future research may be focused on questions such as what selfpresentation of a company as a family business can bring to a company, for whom a family business defines itself, whether customers truly prioritize family businesses over others, whether the family name represents symbolic capital even after transferring the company to subsequent generations, whether successor generations bring the mental stereotypes of company founders with them to their marketing management, etc.

The question arises as to whether to continue in research of marketing vitality in the fixedly specified eight points - the outputs of research for the past four years are similar or whether to focus on specific analysis of one or two selected marketing activities. It would be interesting to confront tools of digital marketing with tools of classical off-line marketing not only from the company perspective, but above all with regard to the needs, requirements, and expectations of customers and the 
fulfillment thereof. Research into the modern marketing management of a company must be connected to the wider cross-disciplinary links to the management of family and nonfamily businesses, with psychology, sociology, to incorporate it into the existing economic/ political and market environment. Subsequent research into overall marketing vitality can be carried out in 3 to 5 years. Such research allows us to evaluate whether the use of trend tools will have a realistic influence on the economic success of companies.

In the area of creation and execution of marketing strategy with the use of modern communications tools, companies have significant reserves; particularly in companies with a smaller number of employees the marketing practices are not by far at the level required by the onset of new technologies. If the state or educational institutions could create truly functioning support for training in the use of marketing, if company owners could lay claim to knowledge about digitization and Marketing 4.0 tools, if examples of best practices could be published, the aversion of owners of many companies to implementing changes could be mitigated. And yet they would have to be convinced that the investment, time, and effort expended on implementing marketing trend tools will be recouped in the shortest period of time.

In conclusion it can be said that, from the perspective of marketing vitality, one of the currently more significant weaknesses of smaller companies in particular of both family and non-family types is a missing or insufficient strategy for realization of marketing activities. Only then would it be possible to implement a super structural tool - to digitize the activity. The capability of companies to create and regularly update a strategic marketing plan with emphasis on the innovation activities of companies focused on the digital tools of the marketing mix. Based of the statistical analyses conducted, the relationship was confirmed between the level of marketing vitality and the amount of sales and the level of marketing vitality and company size measured by number of employees. The question of whether a cause of the success of companies is higher investment into marketing activities, or whether effective marketing activities are a carrier of success, is a subject for subsequent review.

\section{Limitations}

The research has several restrictions or limits. This primarily consists of self-evaluation, albeit performed as part of a semi-structured interview with a trained survey tech. The point assessment may be dimensioned above or below depending on the ego and knowledge of the respondent. The study is limited by the number of respondents willing to participate in the research. For this segment of companies the issue is not a high priority - family businesses founded after 1989 are undergoing a period of transformation to a larger company or are addressing the long-term process of transferring the company to the oncoming generation, entering international markets, etc. (Petrů, Tomášková, \& Krošláková, 2019). The economy is thriving, its growth driven by expenditures for final consumption by households, investment activities of companies and the government. External risks, or prognoses warning of tension in commercial relationships at an international level, of a significant slowdown of the German economy, etc. still do not take into account a factor that could significantly impact their business. The issues of trend tools are the focus more of the younger generation, which nonetheless thus far lacks the authority to decide on the implementation of new technologies. There is not yet any known statistical data giving a real number of family businesses. Other limitations consist of statistical interpretation of results. From the results presented in Tab. It is clear that both with family and non-family businesses there has not been any significant increase in overall marketing vitality in the years studied. The same can be said for the individual assessed indicators. To verify accuracy, the results were tested according to the Pearson coefficient, variation coefficient, and Student's distribution. All three tests showed that the results obtained for the year 2019 are not probable and reflect a high error rate. It is not therefore possible to reach the categorical and valid conclusion that no progress in marketing vitality has occurred among the companies studied, nor can the average valid values of the point assessment of marketing vitality from 2019 be denied. The variation in the results $\left(\mathrm{H}_{3}\right)$ of the Pearson correlation coefficient confirms the assumption that the success of a company takes more than just quality marketing. Another limitation consists of the fact that in the case of 
family businesses the style of business is based primarily on relationships and emotions. An assessment of these factors using quantitative research and advanced statistical methods is imprecise and misleading, as every company is original, unique, and irreplaceable thanks to its know-how. Their benefit in functions of a social, cultural, ecological, philanthropic, and other nature is very difficult to quantify.

Acknowledgment: The result was created in solving the student project "Financial versus sociopsychological factors of family business" using objective oriented support for specific university research of the University of Finance and Administration. We are grateful also to representatives of companies who were willing to participate in the survey.

\section{References}

Acosta-Prado, J. C., Longo-Somoza, M., \& Lozano, M. B. (2017). Does family ownership affect innovation activity? A focus on the biotechnological industry. Innovar, 27(65), 11-23. http://dx.doi.org/10.15446/innovar.v27n65.64886

Anderson R. C., \& Reeb, D. M. (2003). Founding-Family Ownership and Firm Performance: Evidence from the S\&P 500. The Journal of Finance, 58(3), 1301-1328. http://dx.doi.org/10.1111/1540-6261.00567

Binz Astrachan, C., \& Botero, I. (2018). We are a family firm: An exploration of the motives for communicating the family business brand. Journal of Family Business Management, 8(1), 2-21. http://dx.doi.org/10.1108/JFBM-01-2017-0002

Binz Astrachan, C., \& Astrachan, J. H. (2015). Family Business Branding: Leveraging Stakeholder Trust. London: IFB Research Foundation.

Botero, I. C., Thomas, J., Graves, C., \& Fediuk, T. A. (2013). Understanding multiple family firm identities: an exploration of the communicated identity in official websites. Journal of Family Business Strategy, 4(1), 12-21. http://dx.doi.org/10.1016/j.jfbs.2012.11.004

Cailluet, L., Bernhard, F., \& Labaki, R. (2018). Family firms in the long run: the interplay between emotions and history. Entreprises et histoire, 91, 5-13. http://dx.doi.org/10.3917/ eh.091.0005

Ceja, L., Agulles, R., \& Tàpies, J. (2010). The Importance of Values in Family-Owned Firms (Working Paper No. 875). Pamplona: University of Navarra, IESE Business School.
Retrieved July, 2010, from https://core.ac.uk/ download/pdf/6259595.pdf

Chebbi, H., Yahiaoui, D., Thrassou, A., \& Vrontis, D. (2013). The Exploration Activity's Added Value into the Innovation Process. Global Business and Economics Review, 15(2/3), 265-278. http://dx.doi.org/10.1504/ GBER.2013.053073

Colli, A., \& Rose, M. (2016). Family Business. In G. G. Jones \& J. Zeitlin (Eds.), The Oxford Handbook of Business History. Oxford: Oxford University Press. http://dx.doi.org/10.1093/ oxfordhb/9780199263684.003.0009

Dana, L.-P., \& Ramadani, V. (Eds.). (2015). Family Businesses in Transition Economies. Management, Succession and Internationalization. Cham: Springer. http://dx.doi.org/10.1007/978-3-319-14209-8

Davis, J. A. (2017). The Three-Circle Model of the Family Business System. Retrieved from http://johndavis.com/three-circle-model-familybusiness-system/

Denison, D., Lief, C., \& Ward, J. L. (2004). Culture in Family-Owned Enterprises: Recognizing and Leveraging Unique Strengths. Family Business Review, 17(1), 61-70. http://dx.doi.org/10.1111/j.1741-6248.2004.00004.x

Duke Perspective. (2019). The Vitality of Creative Marketing in Modern Business. Retrieved March 9, 2019, from https://sites. duke.edu/perspective/2019/03/09/the-vitalityof-creative-marketing-in-modern-business

Even, Y. (2017). Family Business the Growth DNA of Family Business. Retrieved from http:// www.ey.com/lu/en/services/specialty-services/ family-business-services/family-businessservices_growth-dna-of-family-business

Ferramosca, S., \& Ghio, A. (2018). Accounting Choices in Family Firms: An Analysis of Influences and Implications. Cham: Springer. https://doi.org/10.1007/978-3-319-73588-7

Gottschalk, S. (2017). ZEW News: Family Firms Employing More and More People in Germany and Abroad. Retrieved from http://www.zew.de/en/das-zew/aktuelles/ familienunternehmen-steigern-beschaeftigungim-in-und-ausland/

Habbershon, T. G., Williams, M., \& MacMillan, I. C. (2003). Unified systems perspective of family firm performance. Journal of Business Venturing, 18(4), 451-465. http://dx.doi.org/10.1016/S0883-9026(03)00053-3

Horčičková, Z., \& Stasiulis, N. (2019). Participation of Young People in Family 
Business. Filosofija. Sociologija, 30(1), 17-26. http://dx.doi.org/10.6001/fil-soc.v30i1.3912

Jelínková, E., \& Jiřincová, M. (2015). Diversity Management as a Tool of Managing Intellectual Capital. Journal of Competitiveness, 7(4), 3-17. http://dx.doi.org/10.7441/joc.2015.04.01

Kamei, K., \& Dana, L.-P. (2012). Examining the impact of new policy facilitating SME succession in Japan: From a viewpoint of risk management in family business. International Journal of Entrepreneurship and Small Business, 16(1), 60-70. http://dx.doi. org/10.1504/IJESB.2012.046917

Kammerlander, N., \& van Essen, M. (2017). Family Firms Are More Innovative Than Other Companies. Harvard Business Review. Retrieved from https://hbr.org/2017/01/ research-family-firms-are-more-innovativethan-other-companies

Keller, L. K., \& Lehmann, R. D. (2006). Brands and Branding: Research Findings and Future Priorities. Marketing Science, 25(6), 551765. http://dx.doi.org/10.1287/mksc. 1050.0153

Ključnikov A., \& Sobeková Majková M. (2016). Impact of Gender in the Perception of Administrative Burdens among Young Entrepreneurs - Evidence from Slovakia. Journal of Competitiveness, 8(2), 17-30. http://dx.doi.org/10.7441/joc.2016.02.02

Kotler, P., Kartajaya, H., \& Setiawan, I. (2016). Marketing 4.0: Moving from Traditional to Digital. Hoboken, NJ: John Wiley \& Sons.

Kotler, P., Kartajaya, H., \& Setiawan, I. (2018). Marketing 4.0: When Online Meets Offline, Style Meets Substance, and Machineto-Machine Meets Human-to-Human.

The Marketing Journal.

Kraiczy, N. (2013). Innovations in small and medium-sized family firms. Wiesbaden: Springer Gabler. https://doi.org/10.1007/978-3658-00063-9

Mashchak, N., \& Dovhun, O. (2020). Modern Marketing and Logistics Approaches in the Implementation of E-Commerce. In Integration of Information Flow for Greening Supply Chain Management (pp. 375-391). http://dx.doi. org/10.1007/978-3-030-24355-5_19

Negricea, C. I., \& Purcarea, I. M. (2018). Digital marketers challenged to drive results within the connected world. Holistic Marketing Management Journal, 8(3), 8-13.

Nurita, P., \& Lundia, I. (2017). The mapping of internet marketing potential for SMEs working on indonesian traditional fabrics.
Bisnis \& Birokrasi, 24(1), 14-24. http://dx.doi. org/10.20476/jbb.v24i1.9465

Osunde, C. (2017). Family Businesses and Its Impact on the Economy. Journal of Business \& Financial Affairs, 6(251), 1-3. http://dx.doi. org/10.4172/2167-0234.1000251

Parada, M. J., \& Gimeno, A. (2016). Understanding characteristics of long-term value creating family businesses. Effective Executive, 19(4), 43-54.

Petrů, N., \& Zich, F. (2017). Evaluation of family business marketing activities. In $D$. Petranová, L. Čábyová, \& Z. Bezáková (Eds.), Proceedings from International Scientific Conference Marketing Identity 2017 (pp. 397-410). Trnava: University of Ss. Cyril and Methodius.

Petrů, N., Havlíček, K., \& Tomášková, A. (2018). Comparison of Marketing Vitality of Family and Non-Family Companies doing Business in theCzech Republic. Economics and Sociology, 11(2), 138-156. http://dx.doi. org/10.14254/2071-789X.2018/11-2/10

Petrů, N., Pavlák, M., \& Polák, J. (2019) Factors impacting startup sustainability in the Czech Republic. Innovative Marketing, 15(3), 1-15. http://dx.doi.org/10.21511/ im.15(3).2019.01

Petrů, N., Tomášková, A., \& Krošláková, M. (2019). Diversification of export territories of family businesses as a tool of their further development. Problems and Perspectives in Management, 17(3), 306-322. http://dx.doi. org/10.21511/ppm.17(3).2019.25

Plamínek, J. (2014). Diagnostika a vitalizace firem a organizací: teorie vitality $v$ podnikatelské a manažerské praxi. Praha: Grada.

Poza, E. J. (2014). Family Business. Boston, MA: Cengage.

Quaye, D., \& Mensah, I. (2019). Marketing innovation and sustainable competitive advantage of manufacturing SMEs in Ghana. Management Decision, 57(7), 1535-1553. http://dx.doi.org/10.1108/md-08-2017-0784

Raab, G., Ajami, R. A., Gargeya, V. B., \& Goddard, G. J. (2016). Customer Relationship Management: A Global Perspective. Aldershot: Gower Publishing.

Rahman, M. H., Galván, R. S., \& Martínez, A. B. (2017). Impact of Family Business on Economic Development: A Study of Spain's Family-owned Supermarkets. Journal of Business and Management Sciences, 5(4), 129-138. http://dx.doi.org/10.12691/jbms-5-4-4 
Ramadani, V., \& Hoy, F. (2015). Context and Uniqueness of Family Businesses. In L.-P. Dana, V. Ramadani (Eds.), Family Businesses in Transition Economies (pp. 9-37). Cham: Springer. http://dx.doi.org/10.1007/978-3-31914209-8_2

Rosalina, V., Hamdan, H., \& Triayudi, A. (2019). Electronic Customer Relationship Management (E-CRM) Application as Efforts to Increase Customer Retention of Micro Small and Medium Enterprises (MSMEs) in Banten Indonesia. International Journal of Computer Applications, 181(39), 1-8. http://dx.doi. org/10.5120/ijca2019918310

Sabaitytè, J., Davidavičienè, V., Straková, J., \& Raudeliūnienè, J. (2019). Decision Tree Modelling of E-Consumers' Preferences for Internet Marketing Communication Tools during Browsing. E\&M Ekonomics and Management, 22(1), 206-221. http://dx.doi.org/10.15240/ tul/001/2019-1-014

Serrano-Bedia, A. M., Palma-Ruiz, J. M., \& Flores-Rivera, C. (2019). Innovation and Family Firms. In J. Saiz-Álvarez \& J. Palma-Ruiz (Eds.), Handbook of Research on Entrepreneurial Leadership and Competitive Strategy in Family Business (pp. 371-398). Hershey, PA: IGI Global. http://dx.doi.org/10.4018/978-1-52258012-6.ch018

Shi, H. X. (2014). Entrepreneurship in Family Business. Cham: Springer International Publishing. http://dx.doi.org/10.1007/978-3319-04304-3

Stankovska, I., Josimovski, S., \& Edwards, C. (2016). Digital channels diminish SME barriers: The case of the UK. Economic Research - Ekonomska Istraživanja, 29(1), 217-232. http://dx.doi.org/10.1080/133167 7X.2016.1164926
Sujitha, K. A., \& Johnson, B. (2017). Electronic customer relationship management (e-CRM) techniques for effective banking. In Research Methodology and Statistical Analysis using SPSS (pp. 32-40). New Delhi: Excel India Publishers.

Tagiuri, R., \& Davis, J. A. (1996). Bivalent Attributes of the Family Firm. Family Business Review, 9(2), 199-208. http://dx.doi. org/10.1111/j.1741-6248.1996.00199.x

Tàpies, J., \& Ward, J. L. (Eds.). (2008). Family Values and Value Creation. The Fostering of Enduring Values within Family-Owned Businesses. London: Palgrave Macmillan. https://doi.org/10.1057/9780230594227

Thrassou, A., Vrontis, D., \& Bresciani, S. (2018). The Agile Innovation Pendulum: A Strategic Marketing Multicultural Model for Family Businesses. International Studies of Management and Organization, 48(1), 105-120. http://dx.doi.org/10.1080/00208825. 2018.1407178

Vacek, J., \& Zbránková, M. (2017). Rodinné podnikáni: Manažerský modul. Liberec: Technická univerzita v Liberci.

Vorhies, D. W., Orr, L. M., \& Bush, V. D. (2011). Improving customer-focused marketing capabilities and firm financial performance via marketing exploration and exploitation. Journal of the Academy of Marketing Science, 39(5), 736-756. http://dx.doi.org/10.1007/s11747010-0228-z

Westhead, P. (1997). Ambitions, external environment and strategic factor differences between family and non-family companies. Entrepreneurship \& Regional Development, 9(2), 127-157. http://dx.doi. org/10.1080/08985629700000007 